\title{
The Relationship between High School Physical Education Teacher's Guiding Behavior Type, Learning Attitude, and Learning Commitment
}

\author{
Sung-jin $\mathrm{Ko}^{1}$, Hyun-chul $\mathrm{Cho}^{2}$ and Hyun-ryun $\mathrm{Kim}^{3 *}$ \\ ${ }^{1}$ Graduate Student, Department of Physical Education, Graduate School of Woosuk \\ University, Jeonbuk, Korea \\ ${ }^{2}$ Professor, Department of Physical Education, Woosuk University, Jeonbuk, Korea \\ ${ }^{3}$ Researcher, Sports Welfare Convergence Research Institute,Woosuk University, \\ Jeonbuk, Korea \\ 2chojudo@hanmail.net, ${ }^{3 *}$ khr0615@naver.com
}

\begin{abstract}
The purpose of this study is to empirically on investigate the relationship between learning attitude, learning commitment, and high school physical education teachers' instructional behavior patterns. To achieve this research objective, a population of 484 students enrolled in a male high school located in J City, Jeollabuk-do were selected by convenience sampling, excluding 72 questionnaires that were judged to have inadequate responses after sample collection. A total of 412 parts were used for the final result. The collected data processing was analyzed as follows using the statistical program SPSS Windows 21.0 Version by coding the finally selected facility. The data processing methods were frequency analysis, exploratory factor analysis, and reliability verification (Cronbach's $\alpha$ ). Correlation analysis and multiple regression analysis were conducted to analyze the impact relationship between each variable, and the research results according to the purpose of this study are as follows. First, as for the influence of teacher-guided behavior type on learning attitude, positive rewarding behavior, democratic behavior, and authoritative behavior among the sub-factors of teacher-guided behavior type were excluded from learning attitude, and social support behavior $(\beta=.435, p$. $<.001)$, professor and instructional behavior $(\beta=.203, p<.001)$ were found to have a positive effect. Second, the influence of teacher-guided behavior type on learning commitment was excluded because positive reward behavior and authoritative behavior were not significant among the sub-factors of teacher-led behavior type for learning commitment, and social support behavior $(\beta=.435, p<.001)$, teaching and instruction behavior $(\beta=.203, p<.001)$, and were found to have a positive effect. Third, the influence of learning attitude type on learning commitment is autonomy $(\beta=.365, p<.001)$, attention $(\beta=.282, p<.001)$, interest $(\beta=.258)$ for learning commitment $p<.001)$.
\end{abstract}

Keywords: Physical education teacher, Instructional behavior type, Learning attitude, Learning immersion

\section{Introduction}

Article history:

Received (December 31, 2020), Review Result (January 29, 2021), Accepted (April 10, 2021) 
Teaching and learning in physical education must be systematically conducted so that students can learn the selected learning content most effectively in order to achieve the learning goal. To this end, teachers should understand the direction of teaching and learning and the role of the teacher. It is necessary to focus on considering the characteristics and individual differences of students, familiarity with the planning and organization of teaching and learning, applying teaching methods according to the content area, and grasping points to note in teaching and learning [1]. It means that teachers must make ceaseless efforts and research for the growth and development of students. It means that physical education teachers should not be satisfied with simple technical experience and educated knowledge, but should possess not only general knowledge of physical education, but also personal education [2].

The purpose of physical education is to improve athletic ability through physical activity, to enhance human desire for movement, as well as to improve the quality of life, to inherit and develop sports culture, to maintain physical strength and health, to purify emotions, and to foster sociality. It was defined as a curriculum that simultaneously pursues the external value of, and the ultimate purpose of education for the whole person to foster human beings integrating body, knowledge, and virtues in order to realize such intrinsic and external values. Therefore, school sports are designed to satisfy the movement needs of each student through planned physical activities, improve the motor skills and physical strength necessary for performing exercise, and cultivate the literacy and qualities as a healthy living person to lead a high-quality life. Developing potential physical abilities and ability to adapt to the environment, understanding and utilizing various knowledge about exercise and health [3], maintaining and promoting youth's health, improving physical strength and increasing exercise capacity, and It plays a very important role in social development and moral cultivation [4].

Therefore, in the meaning of school physical education, it is said to be "intentional education to create human beings with the qualities and personality as competent members of society by systematically guiding physical activities and healthy life appropriate for their mental and physical development by considering the needs of students and society." can do. However, when looking at school sports in Korea, the conditions for physical education classes are becoming increasingly difficult [5]. For example, in order to operate physical education class as an entrance exam-oriented curriculum, it is frequently replaced with other subjects. This background includes the ease of physical education teachers, lack of awareness of other subject teachers' physical education, and parents' indifference. It can lead to abnormal physical education classes [6].

In order for the school sports to be operated normally, it is necessary to understand and consider the students who are the subjects of education first. In particular, understanding students in relation to physical education class should be considered first [7]. In fact, in relation to classes, how students perceive physical education subjects, and based on objective data on students' attitudes, appropriate teaching and learning methods should be devised according to their potential abilities, talents, and individual differences [8]. It is up to the teacher's leadership ability to enable learners to learn with willingness to learn. Physical education classes should focus on the teacher's basic position for all students, and should not be biased toward training some students or athletes, and efforts should be made so that the teacher's leadership can normalize school physical education and maximize the efficiency of physical education classes. [9].

When physical education teachers conduct teaching and learning efficiently, students will have fun in class, immerse themselves in class, and expect various learning effects [10]. In order to effectively conduct physical education classes, prior studies of various teaching methods and guidance behavior types have been conducted, but studies on the relationship 
between learning attitude and learning commitment according to the types of guidance behaviors of physical education teachers are insufficient. Therefore, the purpose of this study is to analyze how physical education teachers' behavioral patterns are perceived by students, and the relationship between learning attitudes and learning commitments according to instructional types of physical education teachers.

The purpose of this study is to investigate how the physical education teacher's instructional behavior type affects the learning attitude and learning commitment. In other words, it is to provide basic data for teaching and learning that activates the school's physical education program and manages physical education classes more effectively by analyzing class attitudes and immersion according to the teacher's behavior type to draw interest in learners' physical activities.

The research hypothesis set up to achieve the purpose of this research is as follows.

First, there will be differences in the learning attitude of high school students according to the type of physical education teacher instruction.

Second, there will be differences in the learning commitment of high school students according to the type of physical education teacher instruction.

Third, there will be a correlation between learning attitude and learning commitment.

\section{Research method}

\subsection{Research subject}

The subjects of this study were 484 students enrolled in boys' high school in J City, Jeollabuk-do, and selected a population by convenience sampling, and after collecting samples, 412 copies were finalized, excluding 72 questionnaires that were judged to be inadequate. Used for results. As for the grade, 156 students (37.9\%) in the first grade, 139 students (33.7\%) in the second year, and 117 students $(28.4 \%)$ in the third year. $33.7 \%)$ and 73 people $(17.7 \%)$. The general characteristics of the study subjects are shown in [Table 1].

Table 1. General characteristics of the research subject

\begin{tabular}{|c|c|c|c|}
\hline \multirow{2}{*}{ Variable } & Division & $\begin{array}{c}\text { Frequency } \\
\text { (persons) }\end{array}$ & Ratio (\%) \\
\hline \multirow{2}{*}{ sex } & male & 412 & 100 \\
\hline \multirow{3}{*}{ grade } & 1 grade & 156 & 37.9 \\
\cline { 2 - 4 } & 2 grades & 139 & 33.7 \\
\cline { 2 - 4 } & 3 grades & 117 & 28.4 \\
\hline \multirow{3}{*}{ exercise level } & upper & 139 & 33.7 \\
\cline { 2 - 4 } & middle & 200 & 48.5 \\
\cline { 2 - 4 } & lower & 73 & 17.7 \\
\hline \multirow{2}{*}{ Total } & 250 & 100 \\
\hline
\end{tabular}

\subsection{Investigation tool}

1) Instructional behavior type

The questionnaire on the types of guidance behavior used in this study is based on the behavior test sheet (Chelladurai, P. \& Carron, AV 1978) developed to measure the behavior of leaders (Kwon Soon-Seok, 2001; Jeong-Soo Jeong, 2003; Kim Yong-Ki, 2004; Shin Hyeon- 
suk, 2005; Lim Bong-ho, 2008), etc. The questionnaire used in the study was revised and supplemented to suit this study. Contents consisted of 25 questions including professor and instructional behavior (5), democratic behavior (7), authoritative behavior (5), social support behavior (4), and positive reward behavior (4). Each question in this questionnaire was composed on a Likert 5-point scale.

2) Learning attitude

The questionnaire on learning attitudes used in this study was developed by the Korea Educational Development Institute (1991), and was used in the research of (Junghee Park, 1997; Bomi Lee, 1999; Jeongdae Kim, 1999; Yoonjeong Kwon, 2002). Reorganized into questionnaire questions appropriate to the content. The contents consisted of a total of 18 questions such as interest (6), attention (7), and autonomy (5). Each question in this questionnaire was composed on a Likert 5-point scale.

3) Learning immersion

The questionnaire on learning commitment used in this study was developed by Csikszentmihalyi (1975) and developed by Csikszentmihalyi (1975) as a scale developed by Lee Jong-gil (1992) as a comprehensive definition of Park Geun-soo (2006) commitment factor. Therefore, what was used in the research of Yoo Young-seop (2015) and others was reorganized into questionnaire items suitable for the contents of this study. Contents include self-purpose experience (4), immersion in the content of physical education (7), integration into the physical education course (5), matching of class behavior and consciousness (7), challenge and control (4) It consisted of a total of 27 questions. Each question in this questionnaire was composed on a Likert 5-point scale.

Table 2. Contents of the questionnaire

\begin{tabular}{|c|c|c|}
\hline $\begin{array}{c}\text { Constituent } \\
\text { indicators }\end{array}$ & Composition contents & $\begin{array}{c}\text { Number of } \\
\text { questions }\end{array}$ \\
\hline $\begin{array}{c}\text { General } \\
\text { characteristics }\end{array}$ & Grade, Exercise level & 2 \\
\hline $\begin{array}{c}\text { Guiding } \\
\text { behavior type }\end{array}$ & $\begin{array}{c}\text { Professor and Directive behavior (5), Democratic behavior (7), Authoritative } \\
\text { behavior (5), }\end{array}$ & 25 \\
\hline $\begin{array}{c}\text { Learning } \\
\text { attitude }\end{array}$ & Social support behavior (4), Positive reward behavior (4). & 18 \\
\hline $\begin{array}{c}\text { Learning } \\
\text { immersion }\end{array}$ & $\begin{array}{c}\text { Interest (6), Attention (7), Autonomy (5) } \\
\text { Matching of class behavior and consciousness (7), Challenge and sense of } \\
\text { control (4) }\end{array}$ & 27 \\
\hline \multicolumn{2}{c}{ Total } & 72 \\
\hline
\end{tabular}

\subsection{Validity and reliability of research tools}

In this study, the validity and reliability of the research tool were secured according to the following process. The content validity of the items constituting the measurement tool used in this study was verified based on a meeting of experts of three sports teachers and related scholars, and secondarily, 50 male high school students were examined. A pilot test was conducted to confirm the suitability and applicability of the Face Validity.

1) Instructional behavior type 
The results of exploratory factor analysis of the validity test for the instructional behavior type are as follows. As for the teacher guidance behavior type scale, five sub-factors of teaching and instruction behavior, democratic behavior, authoritative behavior, social support behavior, and positive reward behavior were analyzed. As a result, the sample adequacy scale was KMO $=.941$, which was good. Bartlett's phrase as a result of formation test, $\chi 2=6967.743(\mathrm{df}=300$, $\mathrm{p}<.000$ ) was significant. The total variance explanatory power was $61.3 \%$.

2) Learning attitude

The results of the exploratory factor analysis of the validity test for learning attitude are as follows. The learning attitude type scale was three sub-factors of interest, attention, and autonomy. As a result of factor analysis, the sample adequacy scale was $\mathrm{KMO}=.955$, and Bartlett's sphericity test result $\chi 2=5949.530(\mathrm{df}=153, \mathrm{p} .<.000)$. The total variance explanatory power was $65.5 \%$.

3) Learning immersion

The results of the exploratory factor analysis of the validity test for learning commitment are as follows. The learning commitment type scale was three sub-factors of interest, attention, and autonomy. As a result of factor analysis, the sample adequacy scale was $\mathrm{KMO}=.919$, and Bartlett's sphericity test result $\chi 2=8820.639(\mathrm{df}=351, \mathrm{p} .<.000)$. The total variance explanatory power was $70.74 \%$.

\subsection{Investigation procedure}

The research procedure was conducted after the researcher contacted the boys' high school in J city, Jeollabuk-do by telephone, explaining the purpose and purpose of the research, and obtained consent for data collection, and then assisted with the researcher at the appointed time. Researchers personally visited and collected data. For data collection, after the researcher directly explained the purpose and purpose of the study to the subject, a questionnaire was distributed based on the subject who obtained consent, and a questionnaire was written by the self-administrated method, and then immediately collected at the site.

\subsection{Data processing method}

Among the questionnaires collected to achieve the purpose of this study, data that is judged to be unfaithful or less reliable are excluded from the analysis, and the questionnaire judged as reliable data is coded and the statistical program SPSS Windows 21.0 Version is used. It was analyzed as follows using. Frequency analysis was performed to identify general characteristics, and exploratory factor analysis and reliability verification (Cronbach's $\alpha$ ) were performed to verify the validity and reliability of questions. Correlation analysis and multiple regression analysis were conducted to derive research results to analyze the impact relationship between physical education teacher type, learning attitude, and learning commitment.

\subsection{Research limitations}

First, since this study limited male high school students of both $\mathrm{J}$ and $\mathrm{J}$ city as research subjects, there is a limit to generalizing the research results nationwide.

Second, this study has limitations because it reflects only the opinions of students without considering the home environment and personal characteristics of the study subject and the personal abilities of physical education teachers.

\section{Results}


The Relationship between High School Physical Education Teacher's Guiding Behavior Type, Learning Attitude, and Learning Commitment

\subsection{Correlation analysis}

In this study, the correlation coefficient was calculated through Pearson's momentum correlation analysis in order to understand the correlation and direction between the scales of each research unit for the potential variables whose single dimensionality was confirmed. As a result, as shown in [Table 3], the relationship between each factor was found in the same direction as the hypothesis, and the correlation coefficient was smaller than the reference value of .80 for multicollinearity, indicating that there was no problem in multicollinearity.

Specifically, the correlation coefficient between the sub-factors shows a value of -.066 .382 in the authoritative behavior of the teacher guidance type, and the authoritative behavior in the teacher guidance type, learning attitude, and learning commitment has a negative (-) correlation. Excluding this, the correlation coefficient between the sub-factors of learning attitude and learning attitude was found to have a positive (+) correlation in the range of .302 to .851 .

Table 3. Result of correlation analysis between major variables

\begin{tabular}{|c|c|c|c|c|c|c|c|c|c|c|c|c|c|}
\hline Variable & 1 & 2 & 3 & 4 & 5 & 6 & 7 & 8 & 9 & 10 & 11 & 12 & 13 \\
\hline $\begin{array}{l}\text { 1. Professor } \\
\text { and Directive } \\
\text { behavior }\end{array}$ & 1 & & & & & & & & & & & & \\
\hline $\begin{array}{l}\text { 2. Democratic } \\
\text { behavior }\end{array}$ & $.706^{* *}$ & 1 & & & & & & & & & & & \\
\hline $\begin{array}{c}3 . \\
\text { Authoritative } \\
\text { behavior }\end{array}$ & $-.342 * *$ & $-.328 * *$ & 1 & & & & & & & & & & \\
\hline $\begin{array}{l}\text { 4. Social } \\
\text { support } \\
\text { behavior }\end{array}$ & $.625^{* *}$ & $.675^{* *}$ & $\begin{array}{c}-.382 \\
* *\end{array}$ & 1 & & & & & & & & & \\
\hline $\begin{array}{l}\text { 5. Positive } \\
\text { reward } \\
\text { behavior }\end{array}$ & $.668 * *$ & $.694 * *$ & $\begin{array}{c}-.322 \\
* *\end{array}$ & $\begin{array}{c}.707 * \\
*\end{array}$ & 1 & & & & & & & & \\
\hline 6. Interest & $.393 * *$ & $.429 * *$ & $\begin{array}{c}-.239 \\
* *\end{array}$ & $\begin{array}{c}.500^{*} \\
*\end{array}$ & $\begin{array}{c}.363^{*} \\
*\end{array}$ & 1 & & & & & & & \\
\hline 7. Attention & $.488 * *$ & $.430 * *$ & $\begin{array}{c}-.185 \\
* *\end{array}$ & $\begin{array}{c}.529 * \\
*\end{array}$ & $\begin{array}{c}.451 * \\
*\end{array}$ & $\begin{array}{c}.645^{*} \\
*\end{array}$ & 1 & & & & & & \\
\hline 8. Autonomy & $.408 * *$ & $.436^{* *}$ & $\begin{array}{c}-.187 \\
* *\end{array}$ & $\begin{array}{c}.487 * \\
*\end{array}$ & $\begin{array}{c}.394 * \\
*\end{array}$ & $\begin{array}{c}.753 * \\
*\end{array}$ & $\begin{array}{c}.730 * \\
*\end{array}$ & 1 & & & & & \\
\hline $\begin{array}{l}\text { 9. Self- } \\
\text { purpose } \\
\text { experience }\end{array}$ & $.380 * *$ & $.378 * *$ & $\begin{array}{c}-.106 \\
*\end{array}$ & $\begin{array}{c}.384^{*} \\
*\end{array}$ & $\begin{array}{c}.302 * \\
*\end{array}$ & $\begin{array}{c}.673 * \\
*\end{array}$ & $\begin{array}{c}.636^{*} \\
*\end{array}$ & $\begin{array}{l}.769 * \\
*\end{array}$ & 1 & & & & \\
\hline $\begin{array}{c}10 . \\
\text { Immersion in } \\
\text { class content }\end{array}$ & $.385 * *$ & $.405 * *$ & $\begin{array}{l}-.183 \\
* *\end{array}$ & $\begin{array}{c}.477 * \\
*\end{array}$ & $\begin{array}{c}.380^{*} \\
*\end{array}$ & $\begin{array}{c}.851 * \\
*\end{array}$ & $\begin{array}{c}.641 * \\
*\end{array}$ & $\begin{array}{c}.737 * \\
*\end{array}$ & $\begin{array}{c}.730 * \\
*\end{array}$ & 1 & & & \\
\hline $\begin{array}{l}11 . \\
\text { Integration } \\
\text { into the } \\
\text { course }\end{array}$ & $.453 * *$ & $.447 * *$ & $\begin{array}{c}-.166 \\
* *\end{array}$ & $\begin{array}{c}469 * \\
*\end{array}$ & $\begin{array}{c}.429 * \\
*\end{array}$ & $\begin{array}{c}.523^{*} \\
*\end{array}$ & $\begin{array}{c}.643 * \\
*\end{array}$ & $\begin{array}{l}.596^{*} \\
*\end{array}$ & $\begin{array}{c}.594 * \\
*\end{array}$ & $\begin{array}{l}.56 \\
1^{*} \\
*\end{array}$ & 1 & & \\
\hline $\begin{array}{l}\text { 12. Matching } \\
\text { of class } \\
\text { behavior and } \\
\text { consciousness }\end{array}$ & $.417 * *$ & $.465 * *$ & -.066 & $\begin{array}{l}.414 * \\
*\end{array}$ & $\begin{array}{c}.482 * \\
*\end{array}$ & $\begin{array}{c}.430 * \\
*\end{array}$ & $\begin{array}{c}.586^{*} \\
*\end{array}$ & $\begin{array}{c}.587 * \\
*\end{array}$ & $\begin{array}{c}.583 * \\
*\end{array}$ & $\begin{array}{l}.48 \\
7 * \\
*\end{array}$ & $\begin{array}{l}.66 \\
4^{*} \\
*\end{array}$ & 1 & \\
\hline
\end{tabular}




\begin{tabular}{|c|c|c|c|c|c|c|c|c|c|c|c|c|c|}
\hline $\begin{array}{l}\text { 13. Challenge } \\
\text { and sense of } \\
\text { control }\end{array}$ & $.439 * *$ & $.416^{* *}$ & $\begin{array}{c}-.234 \\
* *\end{array}$ & $\begin{array}{c}.430 * \\
*\end{array}$ & $\begin{array}{c}.369^{*} \\
*\end{array}$ & $\begin{array}{c}.399 * \\
*\end{array}$ & $\begin{array}{c}.466 * \\
*\end{array}$ & $\begin{array}{c}417 * \\
*\end{array}$ & $\begin{array}{c}.412 * \\
*\end{array}$ & $\begin{array}{l}.44 \\
5^{*} \\
*\end{array}$ & $\begin{array}{l}.46 \\
0^{*} \\
*\end{array}$ & $\begin{array}{l}.34 \\
7 * \\
*\end{array}$ & 1 \\
\hline
\end{tabular}

\subsection{The Influence of Teacher Guidance Behavior Style on Learning Attitude}

Table 4. Multiple regression analysis on the influence of teacher guidance behavior types on learning attitude

\begin{tabular}{|c|c|c|c|c|c|}
\hline & & $\mathrm{B}$ & Std E & $\beta$ & $\mathrm{t}$ \\
\hline \multirow{3}{*}{ Interest } & (Constant) & 1.604 & .166 & & $9.690^{\text {*** }}$ \\
\hline & $\begin{array}{c}\text { Social Supporting } \\
\text { Behavior }\end{array}$ & .452 & .067 & .387 & $6.739^{* * * *}$ \\
\hline & $\begin{array}{c}\text { Democratic Supporting } \\
\text { Behavior }\end{array}$ & .180 & .062 & .168 & $2.930^{* * *}$ \\
\hline \multicolumn{6}{|c|}{$\mathrm{R}^{2}=.266, \mathrm{~F}=74.017^{* * *}$} \\
\hline \multirow{3}{*}{ Attention } & (Constant) & 1.708 & .129 & & $13.194^{* * * *}$ \\
\hline & $\begin{array}{c}\text { Social Supporting } \\
\text { Behavior }\end{array}$ & .340 & .048 & .367 & $7.025^{* * *}$ \\
\hline & $\begin{array}{c}\text { Professor and Directive } \\
\text { Behavior }\end{array}$ & .209 & .042 & .259 & $4.969^{* * *}$ \\
\hline \multicolumn{6}{|c|}{$\mathrm{R}^{2}=.320, \mathrm{~F}=96.447^{* * *}$} \\
\hline \multirow{3}{*}{ Autonomy } & (Constant) & 1.684 & .140 & & $12.049^{* * * *}$ \\
\hline & $\begin{array}{c}\text { Social Supporting } \\
\text { Behavior } \\
\end{array}$ & .347 & .057 & .354 & $6.134^{* * *}$ \\
\hline & $\begin{array}{c}\text { Democratic Supporting } \\
\text { Behavior }\end{array}$ & .177 & .052 & .197 & $3.417^{* * *}$ \\
\hline \multicolumn{6}{|c|}{$\mathrm{R}^{2}=.258, \mathrm{~F}=71.207^{* * * *}$} \\
\hline
\end{tabular}

In order to find out the causal relationship between the physical education teacher's instructional behavior type and learning attitude, the results of multiple regression analysis were shown in [Table 4].

First, the influence of the teacher-guided behavior type on the sub-factor of interest in learning attitude was excluded from the sub-factors of the teacher-guided behavior type as teaching and instruction behavior, positive reward behavior, and authoritative behavior were not significant for interest. $(\beta=.387, \mathrm{p}<.001)$ and democratic behavior $(\beta=.168, \mathrm{p}<.001)$ showed a positive effect. The $\mathrm{F}$ statistical value was 74.017 , the significance probability was .000 , and the explanatory power of the instructional behavior type on the interest level, the sub-factor of learning attitude, was found to be $27 \%$.

Second, the influence of the teacher-guided behavior type on the sub-factor attention, democratic behavior, positive reward behavior, and authoritative behavior among the subfactors were excluded, and social support behavior $(\beta=.367, \mathrm{p}<.001)$. Teaching and instruction behavior $(\beta=.259, \mathrm{p}<.001)$ had a positive effect. The $\mathrm{F}$ statistical value was 96.447 , the significance probability was .000 , and the explanatory power of the instructional behavior type on the sub-factor of learning attitude was $32 \%$.

Third, the influence of the teacher-guided behavior type on the sub-factor autonomy of the learning attitude was excluded as the sub-factors were not significant for teaching and 
The Relationship between High School Physical Education Teacher's Guiding Behavior Type, Learning Attitude, and Learning Commitment

instruction behavior, positive reward behavior, and authoritative behavior, and social support behavior $(\beta=.354, \mathrm{p}<.001)$, and democratic behavior $(\beta=.197, \mathrm{p}<.001)$. The F statistical value was 71.207 , the significance probability was .000 , and the explanatory power of the instructional behavior type on the autonomy, the sub-factor of learning attitude, was found to be $26 \%$.

Table 5. Multiple regression analysis on the influence of teacher guidance behavior types on learning commitment

\begin{tabular}{|c|c|c|c|c|c|}
\hline & & $\mathrm{B}$ & Std E & $\beta$ & $\mathrm{t}$ \\
\hline \multirow{3}{*}{$\begin{array}{l}\text { Self-purpose } \\
\text { experience }\end{array}$} & (Constant) & 1.772 & .165 & & $10.762^{* * *}$ \\
\hline & Social Supporting Behavior & .426 & .067 & .373 & $6.388^{* * * *}$ \\
\hline & $\begin{array}{c}\text { Democratic Supporting } \\
\text { Behavior }\end{array}$ & .161 & .061 & .153 & $2.625^{* *}$ \\
\hline \multicolumn{6}{|c|}{$\mathrm{R}^{2}=.240, \mathrm{~F}=64.532^{* * *}$} \\
\hline \multirow{3}{*}{$\begin{array}{l}\text { Immersion in } \\
\text { class content }\end{array}$} & (Constant) & 1.850 & .165 & & $11.193^{* * *}$ \\
\hline & Social Supporting Behavior & .258 & .062 & .240 & $4.178^{* * * *}$ \\
\hline & $\begin{array}{c}\text { Professor and Directive } \\
\text { Behavior }\end{array}$ & .216 & .054 & .231 & $4.020^{* * *}$ \\
\hline \multicolumn{6}{|c|}{$\mathrm{R}^{2}=.180, \mathrm{~F}=44.758^{* * *}$} \\
\hline \multirow{4}{*}{$\begin{array}{l}\text { Integration into } \\
\text { the course }\end{array}$} & (Constant) & .870 & .221 & & $3.936^{* * * *}$ \\
\hline & Positive reward behavior & .312 & .055 & .331 & $5.627^{* * *}$ \\
\hline & $\begin{array}{c}\text { Democratic Supporting } \\
\text { Behavior }\end{array}$ & .263 & .056 & .278 & $4.716^{* * *}$ \\
\hline & Authoritative behavior & .142 & .048 & .132 & $2.943^{* *}$ \\
\hline \multicolumn{6}{|c|}{$\mathrm{R}^{2}=.280, \mathrm{~F}=53.018^{* * * *}$} \\
\hline \multirow{3}{*}{$\begin{array}{l}\text { Matching of } \\
\text { class behavior } \\
\text { and } \\
\text { consciousness }\end{array}$} & (Constant) & 2.005 & .143 & & $14.017^{* * * *}$ \\
\hline & $\begin{array}{c}\text { Professor and Directive } \\
\text { Behavior } \\
\end{array}$ & .235 & .047 & .280 & $5.049^{* * *}$ \\
\hline & Social Supporting Behavior & .246 & .054 & .255 & $4.599^{* * * *}$ \\
\hline \multicolumn{6}{|c|}{$\mathrm{R}^{2}=.233, \mathrm{~F}=62.023^{* * *}$} \\
\hline \multirow{4}{*}{$\begin{array}{l}\text { Challenge and } \\
\text { sense of control }\end{array}$} & (Constant) & 1.670 & .136 & & $12.262^{* * *}$ \\
\hline & Social Supporting Behavior & .236 & .056 & .252 & $4.219^{* * *}$ \\
\hline & $\begin{array}{c}\text { Professor and Directive } \\
\text { Behavior } \\
\end{array}$ & .163 & .051 & .200 & $3.205^{* * *}$ \\
\hline & $\begin{array}{c}\text { Democratic Supporting } \\
\text { Behavior } \\
\end{array}$ & .117 & .057 & .136 & $2.058^{*}$ \\
\hline \multicolumn{6}{|c|}{$\mathrm{R}^{2}=.269, \mathrm{~F}=50.128^{* * *}$} \\
\hline
\end{tabular}

${ }^{*} p<.05, * * p<.01, * * * p<.001$

\subsection{The influence of teacher guidance behavior style on learning commitment}

In order to find out the causal relationship between physical education teacher's instructional behavior type and learning commitment, the results of multiple regression analysis were shown in [Table 5].

First, the influence of the teacher-guided behavior type on the self-objective experience, which is a sub-factor of learning commitment, was excluded because teaching and instruction behavior,

Authoritative behavior, and positive reward behavior were not significant among the subfactors, and social support behavior $(\beta=.373, \mathrm{p}<.001)$ and democratic behavior $(\beta=.153, \mathrm{p}<.01)$ 
had a positive effect. The F statistic value was 64.532 , the significance probability was .000 , and the explanatory power of the instructional behavior type on the lower self-purpose experience of class commitment was $24 \%$.

Second, the influence of the teacher-guided behavior type on the immersion of the lowerlevel physical education content of class commitment was excluded because democratic behavior, authoritative behavior, and positive reward behavior were not significant among the lower factors, and social support behavior $(\beta=.240, \mathrm{p} .<.001)$ and teaching and instruction behavior $(\beta=.231, p<.001)$ had a positive effect. The $F$ statistic value was 44.758 , the significance probability was .000 , and the explanatory power of the instructional behavior type on the lower-level physical education content of class commitment was $18 \%$.

Third, the influence of the teacher-guided behavior type on the integration of the sub-class course of learning immersion was excluded as the sub-factors of teaching, instructional behavior, and social support behavior were not significant, and positive reward behavior $(\beta=.331, \mathrm{p}<.001)$.), democratic behavior $(\beta=.278, \mathrm{p}<.001)$, and authoritative behavior $(\beta=.132$, $\mathrm{p}<.01)$. The $\mathrm{F}$ statistic value was 53.018 , the significance probability was .000 , and the explanatory power of the instructional behavior type on the integration of the lower physical education course of instructional commitment was $28 \%$.

Fourth, the influence of the teacher-guided behavior type on the lower-class behavior and consciousness agreement of learning commitment was excluded because democratic behavior, authoritative behavior, and positive reward behavior were not significant among the lower factors, and teaching and instruction behavior $(\beta=.280, \mathrm{p} .<.001)$ and social support behavior $(\beta=.255, \mathrm{p}<.001)$ were found to have a positive effect. The statistical value of $F$ was 62.023 , the probability of significance was .000 , and the explanatory power of the instructional behavior type on the lower level of instructional commitment and consciousness agreement was $23 \%$.

Fifth, the influence of the teacher-guided behavior type on the sub-challenge and sense of control of learning commitment was excluded because the authoritative behavior and positive reward behavior were not significant among the sub-factors, and social support behavior ( $\beta=.252, p<.001)$, It was found that teaching and instruction behavior $(\beta=.200, p<.001)$ and democratic behavior $(\beta=.136, p<.05)$ had a positive effect. The $F$ statistic value was 50.128 , the significance probability was .000 , and the explanatory power of the instructional behavior type on the lower-class behavior and consciousness agreement of class commitment was $27 \%$.

\subsection{The effect of learning attitude on learning commitment}

The results of multiple regression analysis were shown in $\langle$ Table 6$\rangle$ to find out the causal relationship between learning attitude and learning commitment.

Looking at the results of regression analysis on the relationship between learning attitude and the influence of learning commitment, autonomy $(\beta=.365, p<.001)$, attention $(\beta=.321$, $\mathrm{p}<.001)$, interest in learning commitment $(\beta=.258, \mathrm{p}<.001)$ showed a positive effect. The statistical value of $\mathrm{F}$ was 354.848 , the probability of significance was .000 , and the explanatory power of learning attitude was $72 \%$.

Table 6. Multiple regression analysis of the effect of learning attitude on learning commitment

\begin{tabular}{|c|c|c|c|c|c|}
\hline & & B & Std E & $\beta$ & $\mathrm{t}$ \\
\hline \multirow{3}{*}{$\begin{array}{c}\text { Learning } \\
\text { immersion }\end{array}$} & (Constant) & .739 & .084 & & $8.824^{* * * *}$ \\
\cline { 2 - 6 } & Autonomy & .303 & .038 & .365 & $8.050^{* * * *}$ \\
\cline { 2 - 6 } & Attention & .282 & .034 & .321 & $8.238^{* * *}$ \\
\hline
\end{tabular}


The Relationship between High School Physical Education Teacher's Guiding Behavior Type, Learning Attitude, and Learning Commitment

\begin{tabular}{|l|c|c|c|c|c|}
\hline & Interest & .180 & .028 & .258 & $6.368^{* * *}$ \\
\hline \multicolumn{6}{|c|}{$\mathrm{R}^{2}=.723, \mathrm{~F}=354.848^{* * *}$} \\
\hline$* * * p<.001$
\end{tabular}

\section{Conclusion}

The purpose of this study is to empirically investigate the relationship between physical education teacher's instructional behavior type and learning attitude and learning commitment, and the following conclusions were obtained.

First, as for the influence of teacher-guided behavior type on learning attitude, positive rewarding behavior, democratic behavior, and authoritative behavior among the sub-factors of teacher-guided behavior type were excluded from learning attitude, and social support behavior $(\beta=.435, \mathrm{p} .<.001)$, professor and instructional behavior $(\beta=.203, \mathrm{p}<.001)$ were found to have a positive effect.

Second, the influence of teacher-guided behavior type on learning commitment was excluded because positive rewarding behavior and authoritative behavior were not significant among the sub-factors of teacher-led behavior type for learning commitment, and social support behavior $(\beta=.435, \mathrm{p}<.001)$, instructional behavior with professors $(\beta=.203, \mathrm{p}<.001)$, and were found to have a positive effect.

Third, the influence of learning attitude type on learning commitment is autonomy $(\beta=.365$, $\mathrm{p}<.001)$, attention $(\beta=.282, \mathrm{p}<.001)$, interest $(\beta=.258)$ for learning commitment, $\mathrm{p}<.001)$.

\section{References}

[1] Y. H. Park, "A study on the physical education attitude of elementary school students," Unpublished master's thesis, Graduate School of Education, Korea National University of Education, (2004)

[2] I. Kang, "A survey of high school students' perceptions of physical education classes," Unpublished master's thesis, Yongin University Graduate School of Education, (2001)

[3] H. Kim, "A study on the satisfaction of middle and high school students in physical education classes," Unpublished master's thesis, Graduate School of Korea National University of Education, (2003)

[4] S. G. Kim, "Problems and improvement measures of secondary physical education in national sports," The Korean Sports Association, the 21st National Sports Promotion Seminar, (2002)

[5] J. Y. Kim, "A survey of the satisfaction of middle school students with physical education classes," Unpublished master's thesis, Woosong University Graduate School of Education, (2009)

[6] D. E. Park "A study on the satisfaction of high school students in physical education classes," Unpublished master's thesis, Hanyang University Graduate School of Education, (2005),

[7] C. Y. Jeon, "The relationship between the class guidance type of high school physical education teacher and the student's physical education class attitude," Unpublished master's thesis, Sejong University Graduate School of Education, (2001)

[8] S. G. Kim, C. Y. Jeon, and G. H. Ga, "The relationship between high school physical education teacher's class instruction type and student's class attitude," Journal of the Korean Physical Education Association, vol.38, no.4, pp.277-28, (2001)

[9] E. Hong, "Middle school students' satisfaction with physical education classes according to physical education teacher's leadership behavior types," Unpublished master's thesis, Graduate School of Education, Korea National Sport University, (2006) 
[10] J. B. Yoon, "The effect of physical education teacher's teaching style on middle school students' learning commitment and class satisfaction," Unpublished master's thesis, Chosun University Graduate School of Education, (2015)

\section{Authors}

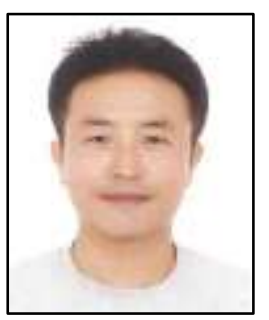

\section{Sung-jin Ko}

Woosuk Univ. Physical Education Major. B.PE

Woosuk Univ. Physical Education Major. M.PE

Woosuk Univ. Physical Education Major. Ph.D. Candidate

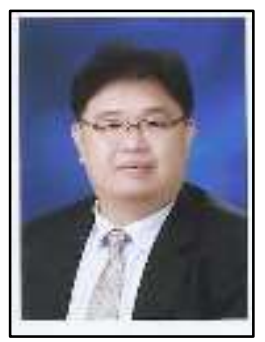

\section{Hyun-Chul Cho}

Woosuk Univ. Physical Education Major. B.PE

Woosuk Univ. Physical Education Major. M.PE

Woosuk Univ. Physical Education Major. Ph.D.

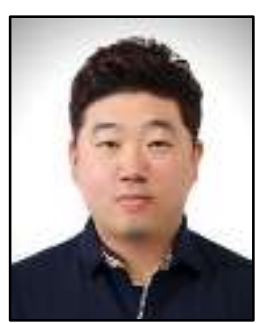

\section{Hyun-ryun Kim}

Uiduk Univ. Physical Education Major. B.PE

Woosuk Univ. Physical Education Major. M.PE

Dankook Univ. Physical Education Major. Ph.D

Woosuk Univ. Institute for Physical Welfare Convergence. Researcher 
The Relationship between High School Physical Education Teacher's Guiding Behavior Type, Learning Attitude, and Learning Commitment

This page is empty by intention. 